\title{
THE EFFECT OF PREGNANT MOTHER'S BEHAVIOR IN THE PRE-PURCHASE STAGE TOWARDS THE SELECTION OF BIRTHPLACE
}

\author{
Pengaruh Perilaku Ibu Hamil pada Tahap Pra Pembelian Terhadap Pemilihan \\ Tempat Persalinan
}

\author{
Novita Aulia Effendy', *Rika Aprilia², Feni Choirun Nisa ${ }^{3}$, Ratna Dwi Wulandari ${ }^{4}$ \\ ${ }^{1}$ Persakmi Surabaya, Indonesia \\ 2,3,4Faculty of Public Health, Universitas Airlangga, Indonesia \\ *Correspondence: rikaaprilia-2016@fkm.unair.ac.id
}

\begin{abstract}
Background: A preliminary study at Mother and Child Hospital of Nyai Ageng Pinatih, Gresik, showed a gap between the number of pregnant women conducting antenatal examinations and the number of deliveries at the hospital in 2011. The number of pregnant women visits for antenatal care was relatively high. It is known that the average number of pregnant mothers giving birth at Mother and Child Hospital of Nyai Ageng Pinatih in 2011 was only $53.85 \%$.

Aims: This study aimed to analyse the effect of maternal behaviour on the pre-purchasing stage during pregnancy in choosing a birth location.

Methods: This research was an analytical study with a cross sectional design. The population of this study was 235 mothers who completed the antenatal care at Mother and Child Hospital of Nyai Ageng Pinatih and were predicted to give birth around March to May 2012. The sample size was 75 people determined by using a cluster sampling method. Each independent variable was tested by identifying the influence on the choice of birth location by using univariate logistic regression with a value of $<0.05$.

Results: The results of this study indicated that maternal behaviour in the pre-purchasing stage of delivery services consists of 3 stages (identification of needs, information seeking, and evaluation of alternatives) that influence the choice of birth place by pregnant mothers. It showed that the pre-purchasing stage has an impact on the choice of delivery place.

Conclusions: The mother's behavior at the pre-purchasing stage during pregnancy influences the choice of delivery place inside and outside Mother and Child Hospital of Nyai Ageng Pinatih. Providing information about maternity care and delivery services can promote services provided at the hospital. The hospital should provide brochures about available services, post posters about health service options available, and promote delivery services conducted by obstetricians or midwives as an alternative delivery service.
\end{abstract}

Keywords: Mother's behaviour, Pre-purchasing stage, Selection of delivery location.

\section{ABSTRAK}

Latar Belakang: Hasil studi pendahuluan di RSIA Nyai Ageng Pinatih menunjukan adanya kesenjangan antara jumlah ibu hamil yang melakukan pemeriksaan antenatal dengan jumlah persalinan di rumah sakit pada tahun 2011. Jumlah kunjungan ibu hamil yang melakukan perawatan antenatal tergolong tinggi. Rata-rata ibu hamil yang melahirkan di RSIA Nyai Ageng Pinatih pada tahun 2011 hanya sebanyak 53,85\%.

Tujuan: Penelitian ini bertujuan untuk menganalisis pengaruh perilaku ibu pada tahap pra pembelian saat kehamilan terhadap pemilihan tempat persalinan.

Metode: Jenis penelitian ini adalah analitik dengan rancang bangun cross sectional. Populasi penelitian ini adalah ibu bersalin yang melakukan pelayanan antenatal di RSIA Nyai Ageng Pinatih dengan tafsiran persalinan pada bulan Maret sampai dengan Mei 2012, yaitu sebanyak 235 orang. Besar sampel adalah 75 orang yang ditentukan dengan metode cluster sampling.

Hasil: Hasil penelitian ini menunjukkan bahwa perilaku ibu pada tahap pra pembelian jasa layanan persalinan yang terdiri dari 3 tahap yaitu identifikasi kebutuhan, pencarian informasi, dan evaluasi alternatif mempengaruhi pemilihan tempat persalinan.

Kesimpulan: Perilaku ibu pada tahap pra pembelian saat kehamilan berpengaruh terhadap pemilihan tempat persalinan di dalam maupun di luar RSIA Nyai Ageng Pinatih. Pemberian informasi mengenai perawatan kehamilan dan layanan persalinan dapat mempromosikan layanan yang diberikan di rumah sakit. Pihak rumah sakit dapat memberikan brosur pilihan layanan kesehatan lengkap di rumah sakit, menempelkan poster mengenai pilihan layanan kesehatan yang tersedia, dan promosi beberapa layanan persalinan yang dilakukan oleh dokter spesialis kandungan atau bidan sebagai alternatif layanan persalinan pasien.

Kata kunci: Perilaku ibu, Tahap pra pembelian, Pemilihan tempat persalinan. 


\section{INTRODUCTION}

Delivery is strongly influenced by an environment and a location where delivery takes place. Ideally, every expectant woman is supported by a good team and facilities, as well as a comfortable and safe environment. The birth location is one of the factors that can affect maternal psychology. The selection of birth location and inappropriate birth attendants will have a direct impact on maternal health (Putri, 2016). Mothers may select the birth location during their pregnancy.

Planning the birth location can be influenced by several factors, such as lifestyles, education, economic condition, husband's support, and environment. For example, pregnant women with high lifestyles, high education, good economic levels, good husband support, and supportive environment will greatly affect them to choose higher-level health facilities, such as hospitals (Baba et al., 2016). Decision-making process which begins with the pre-purchasing stage influences the selection of birth location.

Purchasing decision is a form of consumer behavior in using or consuming a product. Schiffman, Kanuk and Hansen (2012) defined purchasing decision as a selection of two or more alternative choices. For instance, someone has a choice between making a purchase and not making a purchase or between one brand and another brand.

Decision making is an activity in which individuals are directly involved in obtaining and using the goods offered. When buying a product, consumers generally follow decision-making or a step-by-step process used for buying goods or services. This is in accordance with Kotler et al. (2008), who stated that before deciding to buy a product, consumers go through the stages purchasing decision.

The purchasing decision process consists of several stages, such as identification of needs, information seeking, evaluation of alternatives, purchasing decision, and post-purchasing decision behavior (Kotler and Armstrong, 2018). Ives and Learmonth reconciled Customer Resource Life Cycle (CRLF) and suggested that it has three sequential phases including pre-purchasing, during purchasing, and post-purchasing (Dwivedi et al., 2016). The pre-purchasing stage includes identification of needs, information seeking, and evaluation of alternatives.

Mother and Child Hospital of Nyai Ageng Pinatih, Gresik, is a private hospital that specializes in midwifery services in obstetrics and child health. It is supported by several other specialist service units. In carrying out its functions, Mother and Child Hospital of Nyai Ageng Pinatih provides health services for women and children. Based on the preliminary study, the number of pregnant woman visits for antenatal care at Mother and Child Hospital of Nyai Ageng Pinatih was high. The data showed that there were 2285 K4 pregnancies in poly ANC examinations. Nonetheless, only 1204 pregnant women $(52.70 \%)$ had deliveries at Mother and Child Hospital of Nyai Ageng Pinatih.
Meanwhile, the remaining 1081 pregnant women (47.30\%) gave birth outside the Mother and Child Hospital of Nyai Ageng Pinatih. However, the number of pregnant woman visits was not in line with the low number of deliveries with an average of $53.85 \%$ in 2011.

The hospital's performance in providing antenatal services to pregnant women will indirectly have an impact on the assessment of pregnant women in decision-making to use antenatal care at the hospital. Hospitals can strive to improve the quality of their services by paying attention to the completeness of facilities, maintaining the quality of human resources, and organizing integrated hospital management. However, this effort seems to have not been fully implemented in the Mother and Child Hospital of Nyai Ageng Pinatih. There is still a gap between the number of pregnant women who had antenatal examinations and the number of deliveries at the hospital in 2011. Therefore, this study aimed to analyze the influence of decisionmaking during pregnancy for pregnant women in selecting the birthplace at Mother and Child Hospital of Nyai Ageng Piratih.

\section{METHOD}

This research was observational and analytical research with a cross sectional design. The technique of data collection was done by using questionnaires. This study had independent variables and dependent variables. The independent variables consist of identification of needs, information seeking, and evaluation of alternatives in the pre-purchasing stage. Meanwhile, the dependent variable is the choice of birth location. Each independent variable was tested by identifying the influence on the choice of birth location by using univariate logistic regression with $\alpha$ value of $<0.05$.

The population of the study was pregnant women who underwent antenatal services at Mother and Child Hospital of Nyai Ageng Pinatih and were predicted to give birth around March to May 2012 at Mother and Child Hospital of Nyai Ageng Pinatih and outside Mother and Child Hospital of Nyai Ageng Pinatih. The total population of this study was 235 respondents, consisting of 81 women from labor to due date in March, 78 women from labor to due date in April, and 76 women from labor to due date in May. The samples in this study were 75 pregnant women who had antenatal care at Mother and Child Hospital of Nyai Ageng Pinatih with estimated delivery in April 2012, consisting of 21 pregnant women giving birth at Mother and Child Hospital of Nyai Ageng Pinatih, and 54 pregnant mothers giving birth outside Mother and Child Hospital of Nyai Ageng Pinatih .

Samples were taken with a cluster sampling method. The samples in this study were mothers who performed pregnancy care at Mother and Child Hospital of Nyai Ageng Pinatih and delivered at Mother and Child Hospital of Nyai Ageng Pinatih and outside Mother and Child Hospital of Nyai Ageng Pinatih. The cluster sampling criteria in this study are all target populations that actually 
performed antenatal care at Mother and Child Hospital of Nyai Ageng Pinatih and gave birth in April 2012. Samples were divided into 21 respondents who gave birth at Mother and Child Hospital of Nyai Ageng Pinatih and 54 respondents who give birth outside the hospital. The samples of respondents at Mother and Child Hospital of Nyai Ageng Pinatih were chosen by going to delivery rooms and handing out questionnaires and conducting interviews. Meanwhile, the samples of respondents outside Mother and Child Hospital of Nyai Ageng Pinatih were determined by looking at the registration data of pregnant women who had antenatal care at the Gynecology Specialist Clinic. Questionnaire filling was carried out through home visits.

The primary data were obtained from the questionnaires. The questionnaire instruments contained 5 questions about identification of needs, 5 questions about information seeking, and 4 questions about evaluation of alternatives. The questionnaires used a Likert scale ranging from 1 to 4.

The choices of identifying needs include need it highly, need, do not need, and really do not need it. The choices of finding information were very active, active, passive, and very passive. Meanwhile, evaluation of alternatives divides the choices into always, often, rarely, and never. The scores from the respondents' answers were then categorized. The category of results for 2-4 grade was not good, for 5-6 grade 5-6 was good, and for 7-8 grade was very good. The validity and reliability of the questionnaire had been tested and eligible to be used. Based on the results of the validity test, all the question items had $R>0.361$. The results of the analysis showed that the Cronbach Alpha value was greater than $r$ critical (2-sided test) at 5\% significance with df 28 , which was 0.361 . Then, it can be concluded that the items of this research instrument were valid and reliable.

Researchers have made several efforts to overcome possible biases, such as selection bias and information bias. The actions taken are selecting samples using certain criteria and arranging questions systematically and in accordance with the variables under study.

\section{RESULTS AND DISCUSSION}

\section{Characteristics of Respondents}

The respondents' characteristics in this study were distinguished according to age group, education level, occupation, and use of health insurance. Table 1 showed the respondents' characteristics.

Based on Table 1, it can be seen that the number of respondents from older age groups were higher than others, and the lower levels of education of the respondents tend to choose the place of delivery at Mother and Child Hospital of Nyai Ageng Pinatih. Table 1 also shows that respondents with private employment status $(36.8 \%)$ were more likely to choose the place of delivery at Mother and Child Hospital of Nyai Ageng
Pinatih than other employment statuses. Meanwhile, respondents who were civil servants $(90.9 \%)$ were more likely to choose places of delivery outside the Mother and Child Hospital of Nyai Ageng Pinatih. In other aspects, the respondent who never used health insurance during labor were more likely to choose the place of delivery at Mother and Child Hospital of Nyai Ageng Pinatih.

Table 1. The Respondents' Characteristics based on Age Group, Education Level, Occupation, and Use of Health Insurance.

\begin{tabular}{|c|c|c|c|c|}
\hline \multirow{3}{*}{ Characteristics } & \multicolumn{4}{|c|}{ Birthplace } \\
\hline & \multicolumn{2}{|c|}{$\begin{array}{c}\text { At Mother and } \\
\text { Child Hospital } \\
\text { of Nyai Ageng } \\
\text { Pinatih }\end{array}$} & \multicolumn{2}{|c|}{$\begin{array}{c}\text { Outside } \\
\text { Mother and } \\
\text { Child } \\
\text { Hospital of } \\
\text { Nyai Ageng } \\
\text { Pinatih }\end{array}$} \\
\hline & $\mathbf{N}$ & $\%$ & $\mathbf{N}$ & $\%$ \\
\hline \multicolumn{5}{|l|}{ Age } \\
\hline $15-25$ & 8 & 29.7 & 19 & 70.3 \\
\hline $26-35$ & 9 & 22.0 & 32 & 78.0 \\
\hline $36-45$ & 4 & 57.1 & 3 & 42.9 \\
\hline Total & 21 & 28.0 & 54 & 72.0 \\
\hline \multicolumn{5}{|l|}{ Education } \\
\hline $\begin{array}{l}\text { SMP (Middle } \\
\text { School) }\end{array}$ & 6 & 31.6 & 13 & 68.4 \\
\hline $\begin{array}{l}\text { SMA (High } \\
\text { School) }\end{array}$ & 10 & 29.4 & 24 & 70.6 \\
\hline Diploma & 1 & 20.0 & 4 & 80.0 \\
\hline S1 (University) & 4 & 23.5 & 13 & 76.5 \\
\hline Total & 21 & 28.0 & 54 & 72.0 \\
\hline \multicolumn{5}{|l|}{ Occupation } \\
\hline Unemployed & 8 & 25.8 & 23 & 74.2 \\
\hline $\begin{array}{l}\text { Government } \\
\text { employee }\end{array}$ & 1 & 9.1 & 10 & 90.9 \\
\hline $\begin{array}{l}\text { Private } \\
\text { employee }\end{array}$ & 7 & 36.8 & 12 & 63.2 \\
\hline Entrepreneur & 5 & 35.7 & 9 & 64.3 \\
\hline Total & 21 & 28.0 & 54 & 72.0 \\
\hline \multicolumn{5}{|l|}{$\begin{array}{l}\text { Use of Health } \\
\text { Insurance }\end{array}$} \\
\hline Never & 20 & 33.3 & 40 & 66.7 \\
\hline Infrequently & 1 & 20.0 & 4 & 80.0 \\
\hline Often & 0 & 0.0 & 6 & 100.0 \\
\hline Always & 0 & 0.0 & 4 & 100.0 \\
\hline Total & 21 & 28.0 & 54 & 72.0 \\
\hline
\end{tabular}

\section{Identification of Needs}

There are five processes of consumer behavior that each individual goes through in making a purchase. The first stage is identification of needs. Identification of needs is the process by which respondents are aware of needs. Needs are human desires for goods and services that need to be fulfilled to maintain their survival. People find their needs when they face problems in which there is a difference between the desired condition and the fact (Kotler and Keller, 2012). Need for health services is a function of need for individual health based on his experience. There are several factors that affects someone to recognize his needs, such as time, situation change, product ownership, 
product consumption, individual differences and marketing effects (Kotler and Keller, 2012).

Identification of needs can occur to anyone including to pregnant women. During pregnancy, pregnant women will need health services to maintain their and the babies' health. The needs in terms of maternity health involve maternity care and delivery services. Table 2 shows the level of identification of respondents' needs for maternity care and delivery.

Based on Table 2, the level of identification of respondents' needs for maternity care and delivery services at Mother and Child Hospital of Nyai Ageng Pinatih was similar to that outside Mother and Child Hospital of Nyai Ageng Pinatih with good category. From the data of 21 respondents (28.0\%) at Mother and Child Hospital of Nyai Ageng Pinatih and 54 respondents (72.0\%) outside Mother and Child Hospital of Nyai Ageng Pinatih, the findings showed all need maternity care and delivery services at either Mother and Child Hospital of Nyai Ageng Pinatih or outside Mother and Child Hospital of Nyai Ageng Pinatih, which is basically at any other hospitals.

Table 2. Pre-purchasing Maternal Behaviour during Pregnancy towards the Selection of Birth Location in 2012.

\begin{tabular}{|c|c|c|c|c|c|c|c|c|c|}
\hline \multirow{3}{*}{ Variable } & \multirow{3}{*}{ Assessment } & \multicolumn{4}{|c|}{ Place of Delivery } & \multirow{2}{*}{\multicolumn{2}{|c|}{ Total }} & \multirow{3}{*}{ Sig. } & \multirow{3}{*}{$\operatorname{Exp}(B)$} \\
\hline & & \multicolumn{2}{|c|}{$\begin{array}{c}\text { At Mother and } \\
\text { Child Hospital } \\
\text { of Nyai Ageng } \\
\text { Pinatih }\end{array}$} & \multicolumn{2}{|c|}{$\begin{array}{c}\text { Outside } \\
\text { Mother and } \\
\text { Child Hospital } \\
\text { of Nyai Ageng } \\
\text { Pinatih } \\
\end{array}$} & & & & \\
\hline & & $\mathbf{N}$ & $\%$ & $\mathbf{N}$ & $\%$ & $\mathbf{N}$ & $\%$ & & \\
\hline \multirow{2}{*}{$\begin{array}{l}\text { Identification } \\
\text { of Needs }\end{array}$} & Not good & 0 & 0.0 & 0 & 0.0 & 0 & 0.0 & \multirow[t]{2}{*}{0.001} & \multirow[t]{2}{*}{0.009} \\
\hline & Good & 21 & 28.0 & 54 & 72.0 & 75 & 100.0 & & \\
\hline \multirow{4}{*}{$\begin{array}{l}\text { Information } \\
\text { Seeking } \\
\text { Evaluation of } \\
\text { alternatives }\end{array}$} & Not good & 7 & 21.2 & 26 & 78.8 & 33 & 100.0 & \multirow[t]{2}{*}{0.038} & \multirow[t]{2}{*}{10.016} \\
\hline & Good & 14 & 33.3 & 28 & 66.7 & 42 & 100.0 & & \\
\hline & Not good & 19 & 30.2 & 44 & 69.8 & 63 & 100.0 & 0.001 & 3.126 \\
\hline & Good & 2 & 16.7 & 10 & 83.3 & 12 & 100.0 & & \\
\hline
\end{tabular}

Needs can be triggered by internal stimuli when a person's regular need arises at a high level. Needs can also arise due to external stimuli, such as advertisements and influences from other parties triggerring thoughts about the possibility of making a purchase (Kotler and Armstrong, 2018). During pregnancy, the respondents had been encouraged to carry out a maternity care to find out and maintain the health condition of the mother and baby. If the need for maternity services has been fulfilled, pregnant women will determine other needs, such as delivery service.

A study that assessed the needs in three different groups (the resilient group, the vulnerable group, and the disconnected group) revealed that healthcare needs vary between those three groups (Reeve and Cooper, 2016). The resilient group demonstrated existing capacity to interpret and manage problems, so the focus of healthcare should be to minimize further disruption. The vulnerable group revealed needs for more interpretive support to help reduce the burden of medical care and to support continuous investment in daily living. The disconnected group defined health needs by disease or condition status, rather by capacity to adapt and respond to daily living (Reeve and Cooper, 2016).

Health services need to include pregnancy and childbirth if associated with the results of the research from Reeve and Cooper. It can be concluded that a health service aims to find out and manage problems that may occur during pregnancy and childbirth.

\section{Information Seeking}

Information seeking is a stage after the identification of needs. Consumers will look for existing information in their memories or obtain relevant information to their decisions from their environment (Blackwell, Miniard and Engel, 2006). Respondents should look into information about maternity care and delivery services. However, they did not actively seek such information. Information in this study includes information about maternity care and delivery services. According to Kotler and Armstrong (2018), through information retrieval, consumers learn in detail about product identity, such as product brand, product features, and competitors in deciding what to choose in the purchasing process.

The results in terms of respondents' activeness to seek information about maternity care and delivery services can illustrate the level of information seeking at Mother and Child Hospital of Nyai Ageng Pinatih and outside Mother and Child Hospital of Nyai Ageng Pinatih as shown in Table 1. Based on Table 1, it is clear that the better the level of information retrieval of respondents is, the more respondents tend to choose birth location at Mother and Child Hospital of Nyai Ageng Pinatih. On the contrary, if the respondents' information seeking level is worse, they will tend to choose the birth location outside Mother and Child Hospital of Nyai Ageng Pinatih .

The process of purchasing products is a complicated because consumers are not fully aware of the products and services offered. In addition, providers of products and services do not thoroughly describe the characteristics and quality of products, so consumers need to identify product quality through other media, such as online media, to get sufficient information before making a purchase (Bai, Yao and Dou, 2015). 
There are several ways to find information about maternity care and delivery services, including asking people who have childbirth experience, family or close relatives, and doctors or midwives. The most popular way to find information about maternity care and delivery services done by respondents at Mother and Child Hospital of Nyai Ageng Pinatih and outside Mother and Child Hospital of Nyai Ageng Pinatih was by asking a doctor or midwife.

In choosing the birth location, respondents of Mother and Child Hospital of Nyai Ageng Pinatih needed several information. Five respondents of Mother and Child Hospital of Nyai Ageng Pinatih (15.1\%) needed complete information about Mother and Child health, 12 respondents (36.4\%) required information about delivery service rates, and 16 respondents (48.5\%) sought information about types of delivery services. Meanwhile, information needed by respondents outside Mother and Child Hospital of Nyai Ageng Pinatih in selecting the birth location includes Mother and Child health which was chosen by 17 respondents (19.8\%), types of delivery services chosen by 28 respondents $(32.5 \%)$, and delivery service rates chosen by 41 respondents $(47.7 \%)$.

\section{Evaluation of Alternatives}

The third stage in the pre-purchasing decision making process is evaluation of alternatives. Evaluation of alternatives is a buyer's decision process by using information to evaluate a group of alternative products to help them decide. The way consumers evaluate alternatives depends on the consumer and the buying situation. In some cases, consumers use careful calculations and logical thinking while others only evaluate a little or do not even evaluate because they buy the products based on encouragement and intuition (Kotler et al., 2008).

According to Gabbott and Hogg (1998), overall consumers' evaluations of a brand also incorporate summary evaluations of information which represent how consumers feel in a long run, lying in a continuum from positive to negative (Gabbott and Hogg, 1998). Based on Tekin, Yiltay and Ayaz (2016), aiming to find out the factors that influence consumers' behavior in buying luxury goods, it is found that consumers make alternative evaluations before making a purchase.

The respondents described their views about status symbol, quality, style, reputation, prestige, fashion, societal image, respectability, premium price, standing behind the product in case of any problem, and brand trust. Based on these views, it can be concluded that the consumers had made several assessments about the brand before making a purchase decision. Just as in health services, consumers will also compare health services at one hospital with other hospitals.

Evaluation of alternatives is a stage where respondents compare maternity care and delivery services at Mother and Child Hospital of Nyai Ageng Pinatih with a number of other alternatives of giving birth locations. Table 1 also illustrates complete description of respondents' evaluation of alternatives at Mother and Child Hospital of Nyai Ageng Pinatih and outside Mother and Child Hospital of Nyai Ageng Pinatih. The change from bad category $(69.8 \%)$ to good category (83.3\%) suggests that the better the level of respondents' evaluation is, the more respondents will tend to choose birth location outside Mother and Child Hospital of Nyai Ageng Pinatih. In contrast, if the respondent's evaluation level is not good enough, the respondents will tend to choose birth location at Mother and Child Hospital of Nyai Ageng Pinatih. This can be seen from good category $(16.7 \%)$ to bad category $(30.2 \%)$.

There are two things compared by 2 respondents (9.5\%) of Mother and Child Hospital of Nyai Ageng Pinatih in choosing maternity care, which were the completeness of hospital facilities and the pregnancy care fees. Meanwhile, 1 respondent $(1.9 \%)$ who chose outside Mother and Child Hospital of Nyai Ageng Pinatih considered the affordability of hospital location. Another thing compared by 3 respondents $(5.6 \%)$ was the pregnancy care fees. Inspite of comparing maternity care, respondents also considered the delivery services.

As many as three respondents (14.3\%) of Mother and Child Hospital of Nyai Ageng Pinatih compared the complete infrastructure and affordability of hospital location. The other four respondents $(19.0 \%)$ viewed the delivery service fees. Things compared by the respondents outside Mother and Child Hospital of Nyai Ageng Pinatih in choosing delivery services include the staff attitude, which was considered by 1 respondent (1.9\%), complete facilities and infrastructure, which was viewed by 9 respondents (16.7\%), the affordability of hospital location, which was considered by 14 respondents $(25.9 \%)$, and the rate of delivery services, which was viewed by 18 respondents (33.3\%).

\section{Purchasing Stage}

At this stage, consumers make decisions when to buy, where to buy, and how to pay. Purchasing is a function of intention and influence from environment or individual differences (Blackwell, Miniard and Engel, 2006). Buying a product or brand is the most preferred in purchasing decision, but it can be influenced by attitude of others. Other people who are important for someone will influence in making a purchasing decision. Unexpected situational factors also may influence the purchasing decision. For example, consumers form purchasing intentions based on income, price, and expected product benefits (Kotler et al., 2008).

The purchasing stage describes pregnant women's decision to choose birth location at Mother and Child Hospital of Nyai Ageng Pinatih or outside Mother and Child Hospital of Nyai Ageng Pinatih. Based on Table 1, 21 respondents (28\%) chose birth location at Mother and Child Hospital of Nyai Ageng Pinatih while 54 respondents (72\%) chose birth location outside Mother and Child Hospital of Nyai Ageng Pinatih. From the data of delivery in April, it shows that the number of mothers who chose to give birth outside Mother and Child Hospital of Nyai 
Ageng Pinatih was more than that at Mother and Child Hospital of Nyai Ageng Pinatih.

The purchasing stage consists of pretransactional, transactional and post-transactional. In the pre-transactional stage, if there are no references available for the services needed, consumers will seek for information. After the identification of service needed, decision-making process goes through an evaluation of the selected services offered to consumers. According to Kotler et al. (2008), purchases are strongly influenced by cultural, social, personal, and psychological factors.

Some reasons for respondents to give birth at Mother and Child Hospital of Nyai Ageng Pinatih involve ownership of health insurance, previous childbirth experience, affordable rates, affordable distance, family advice, referral by midwives, and existing maternity care. The most frequent reason for respondents in giving birth at Mother and Child Hospital of Nyai Ageng Pinatih is the continuous maternity care received at the hospital. On the other hand, the reasons for respondents choosing birth location outside Mother and Child Hospital of Nyai Ageng Pinatih are due to referral by midwives, unavailability of previously selected doctors, family advice, affordable rates, complete equipment, affordable distance, previous childbirth experience, and health insurance. The most recurrent reasons for them is the ownership of health insurance.

Purchasing decisions occurred because of previous experience, especially by conducting a antenatal care during pregnancy at Mother and Child Hospital of Nyai Ageng Pinatih. This is in accordance with Kotler et al. (2008), who mentioned that purchasing decisions can be influenced by prior learning as a part of psychological factors.

In 2012, insurance ownership became an important factor in choosing the location of health services. In the coming years, insurance ownership greatly influenced consumers to choose health care providers. In 2014, the government launched a national health insurance under BPJS Kesehatan on January 1, 2014 as a transformation from PT Askes (Corporation). Through Indonesian Health CardNational Health Insurance Program (Kartu Indonesia Sehat/KIS-Jaminan Kesehatan Nasional/JKM organized by BPJS Kesehatan, the government ensured that all Indonesians were protected by comprehensive, fair and equitable health insurance.

BPJS Kesehatan will greatly influence the selection of health care facilities. If all hospitals have affiliated with BPJS Kesehatan, a community can choose a hospital as a healthcare provider. The positive impact is that all hospitals will improve their health services to compete with other hospitals. Mother and Child Hospital of Nyai Ageng Pinatih must prepare itself by improving the quality of health services so that patients are satisfied and are able to reselect Mother and Child Hospital of Nyai Ageng Pinatih as their healthcare provider.

\section{Effect of Decision-Making toward the Selection of Birth Location}

The decision-making process of respondents before the selection of birth selection begins with pre-purchasing stages, namely identification of needs, information seeking, and evaluation of alternatives. Table 1 showed the results of three prepurchasing stages in relation to the selection of birth location. Based on Table 1, there are 3 stages in the pre-purchasing stage that influence the selection of birth location, namely identifying needs, seeking information, and evaluating alternatives. The identification of needs with a significance value of 0.001 and Exp. Value $(B)=0.009$ resulted in 0.009 times effects greater than the other stages in terms of birth location choice. The information seeking phase with a significance value of 0.038 and Exp. Value $(B)=10.016$ means that it affects 10.016 times greater than the other stages. Evaluation of alternatives stage with a significance value of 0.001 and Exp. Value $(B)=3.126$ means that it affects 3.126 times greater than the others. The results of this study indicate that consumer purchasing decisions are influenced by a decision-making process consisting of five stages, namely prepurchasing stages (identification of needs, information search, and evaluation of alternatives), purchasing decisions, and post-purchasing behavior.

The pre-purchasing stages include identifying needs, seeking information, and evaluating alternatives which influence the selection of birth location. Based on the results of the influence test, it is known that the tendency of choosing birth location outside Mother and Child Hospital of Nyai Ageng Pinatih was 0.009 times greater than at Mother and Child Hospital of Nyai Ageng Pinatih due to unintentional decisions of using delivery services at that hospital even though they used its maternity services.

Marullyta and Pudjirahardjo (2013), also stated that respondents who were aware of their needs to conduct a antenatal care would initiate to activate the decision process by using antenatal care services. This is because consumer's purchasing decisions start from the identification of needs between the desired situation and the fact sufficiently raising and activating the decision process.

The results of the influence test on the level of information seeking showed the level of respondents' information seeking outside Mother and Child Hospital of Nyai Ageng Pinatih was 10.016 times worse than that of respondents at Mother and Child Hospital of Nyai Ageng Pinatih. Low respondents' information seeking causes them to choose birth location outside Mother and Child Hospital of Nyai Ageng Pinatih. Most respondents are passive in seeking information related to maternity care and delivery services. As a result, when getting information from one trusted party, they do not think of other possible delivery services. For example, midwives refer them to giving birth at a particular hospital, so respondents with less information seeking only follow the midwife's instructions and choose that birth location.

Previous research stated that there was a significant relationship between marketing communication and patients' decision. This indicates that there is an interest and fulfillment of the desired health information that encourages patients to choose a hospital. Promotion is one of the ways to provide information since good and targeted promotion can encourage patients to choose hospitals as their health services (Lestari, 2015). 
Sastrismal and Yasri (2014) in their research also mentioned that consumers could be aware of their needs after they got informed about a product or service. At this stage, promotional activities as external stimuli can be very decisive in the consumer's decision-making process and for prospective consumers so that they will be motivated to know the products in the health care providers.

Widastra (2013) revealed that information obtained by consumers about dental clinic at public health centers came from family, friends or neighbors while the one who could influence others or make decisions to utilize dental clinic at public health centers was the father as the head of family. This study also found promotion efforts must involve family because community behavior affects whether or not the community utilizes health services. Based on the influence test in terms of alternative evaluation with a significance value of 0.001 and Exp. Value $(B)=3.126$, it means that respondents who compare several choices of birth location tend to choose birth location outside Mother and Child Hospital of Nyai Ageng Pinatih for fulfilling their desires.

After evaluating different alternatives, the consumers make the decision to purchase the most suitable alternative, and the final stage comes after purchasing (Wang et al., 2016). According Marullyta and Pudjirahardjo (2013), respondents compared the facilities when conducting a antenatal care, Evaluation of alternatives may determine whether the respondents will do an antenatal care or not in a specific location. About $30 \%$ of respondents stated that they made a list of pregnancy screening options while the rest did not make any list.

Furthermore, consumers are more aware of all aspects involved in the purchase of products (Sharma and Sonwalkar, 2013). This causes consumers to evaluate before making purchasing decisions. Another study mentions that firstly, the evaluations emerged because of a lack of support and services as well as limited choices in terms of treatment options. Second is the understanding of the role of knowledge and type of knowledge, which informs the groups. Then, it can be concluded that if pregnant women get satisfactory pregnancy services and are supported with good knowledge of what types of pregnancy care are at a hospital, they will be less likely to evaluate alternatives (Edwards and Howlett, 2013).

The findings of this research also concluded that respondents who identified needs did seek information about the location of antenatal care services. Mostly, respondents who did antenatal care in the third semester did not conduct evaluation of alternatives. It illustrates that the identification of needs, information seeking, and evaluation of alternatives greatly influence consumers' decisions to choose health services (Marullyta and Pudjirahardjo, 2013).

\section{CONCLUSION}

This study investigated the effects of pregnant mother's behaviour in the pre-purchase stage towards the selection of labor location. It can be concluded that pregnant women's behaviour during pregnancy at the pre-purchasing stage (identifying needs, seeking information, and evaluating alternatives) influences the selection of birthplace. The more passive respondents seek for information about maternity care and delivery services, the more likely they choose a birth location outside Mother and Child Hospital of Nyai Ageng Pinatih. The last step is evaluating alternatives. If respondents' evaluation of alternatives is low, they are likely to give birth at Mother and Child Hospital of Nyai Ageng Pinatih .

Hospitals are expected to improve the quality of maternity care and delivery services provided. Good service quality during maternity care will increase demands for pregnancy care and delivery services at hospitals. Hospitals need to improve the community's comprehension of the various choices of prenatal care and delivery services at the hospitals and increase the intense implementation of promotional activities so that the public is aware of the presence of hospital sickness and available health services.

Providing information about maternity care and delivery services can be one way to promote services provided at the hospital. Some ways that the hospital can do are providing brochures about services available at the hospital, posting posters about health service options available at hospitals, and promoting delivery services conducted by obstetricians or midwives as an alternative delivery service. In addition, hospitals must be able to determine the location of promotional activities that are spread not only in urban areas, but also in rural areas.

Satisfaction with health services and adequate information about health services will minimize patients to compare services at Mother and Child Hospital of Nyai Ageng Pinatih with other health centers. Mother and Child Hospital of Nyai Ageng Pinatih also needs to affiliate with private companies and factories in Gresik City to offer health and social insurances for reducing delivery costs which may increase the delivery visits at the hospital.

\section{CONFLICT OF INTEREST}

The authors declare that they have no conflict of interests.

\section{REFERENCES}

Baba, K. et al. (2016) 'A cross-sectional survey of policies guiding second stage labor in urban Japanese hospitals, clinics and midwifery birth centers', BMC Pregnancy and Childbirth. BMC Pregnancy and Childbirth, 16(37), pp. 1-13. doi: 10.1186/s12884-016-0814-2.

Bai, Y., Yao, Z. and Dou, Y. F. (2015) 'Effect of social commerce factors on user purchase behavior: An empirical investigation from renren.com', International Journal of Information Management. Elsevier Ltd, 35(5), pp. 538550. doi: 10.1016/j.jinfomgt.2015.04.011.

Blackwell, R. D., Miniard, P. W. and Engel, J. F. (2006) Consumer Behavior. 10th edn. United States of America: Thomson/South-Western (International student edition: South Western Publ). Available at: 
https://books.google.co.id/books?id=96TxAAA AMAAJ.

Dwivedi, Y. K. et al. (2016) 'A generalised adoption model for services: A cross- country comparison of mobile health (m-health)', Government Information Quarterly, 33(1), pp. 174-187. Available at: http://doi.org/10.1016/j.giq.2015.06.003.

Edwards, C. and Howlett, E. (2013) 'Putting knowledge to trial: "ADHD parents" and the evaluation of alternative therapeutic regimes', Social Science and Medicine. Elsevier Ltd, 81(34), pp. 34-41. doi: 10.1016/j.socscimed.2013.01.015.

Gabbott, M. and Hogg, G. (1998) Consumers and services. United States: Wiley. Available at: https://books.google.co.id/books?id=D2hEAA AAYAAJ.

Kotler, P. and Armstrong, G. (2008) Prinsip pemasaran. 12th edn. Jakarta: Erlangga. Available at: https://books.google.co.id/books?id=UECwnQ AACAAJ.

Kotler, P. and Armstrong, G. (2018) Principles of Marketing. 17th edn. Toronto: Prentice Hall (The Prentice-Hall series in marketing).

Kotler, P. and Keller, K. L. (no date) Marketing Management. 14th edn. United States: Pearson. doi: 10.1080/08911760903022556.

Lestari, S. P. (2015) 'Hubungan Komunikasi Pemasaran Dan Promosi Dengan Keputusan Memilih Jasa Layanan Kesehatan (Studi Pada Rumah Sakit Islam Lumajang)', Interaksi, 4(2), pp. 139-147. Available at: https://doi.org/10.14710/interaksi.4.2.139-147.

Marullyta, A. and Pudjirahardjo, W. J. (2013) 'Keputusan Pembelian K4 Oleh lbu Hamil Di Wilayah Kerja Puskesmas Tembok Dukuh', Jurnal Administrasi Kesehatan Indonesia, 1(2), pp. 108-119. Available at: https://www.neliti.com/publications/3850/purc hasing-decision-of-pregnant-women-in-fourthvisit-antenatal-care-in-puskesma.

Putri, M. D. (2016) 'FAKTOR-FAKTOR YANG BERHUBUNGAN DENGAN PEMILIHAN TEMPAT PERSALINAN TAHUN 2015 (Studi Di Kecamatan Sarolangun Kabupaten Sarolangun Jambi)', Jurnal Kesehatan Masyarakat, 4(2), pp. 55-67. Available at: https://ejournal3.undip.ac.id/index.php/jkm/arti cle/view/11926.

Reeve, J. and Cooper, L. (2016) 'Rethinking how we understand individual healthcare needs for people living with long-term conditions: A qualitative study', Health and Social Care in the Community, 24(1), pp. 27-38. doi: 10.1111/hsc.12175.

Sastrismal and Yasri (2014) 'Pengaruh Produk, Harga, Lokasi Dan Pelayanan Terhadap Keputusan Pasien Untuk Melakukan Pemeriksaan Di Laboratorium Klinik Setia Labora Kota Payakumbuh', Jurnal Riset Manajemen Bisnis dan Publik, 2(1). Available at:

http://ejournal.unp.ac.id/index.php/jrmbp/articl e/view/4201.

Schiffman, L. G., Kanuk, L. L. and Hansen, H. (2008)
Consumer Behaviour: A European Outlook. Prentice Hall/Financial Times. Available at: https://books.google.co.id/books?id=kf9TuQA ACAAJ.

Sharma, V. and Sonwalkar, J. (2013) 'Does Consumer Buying Behavior Change During Economic Crisis?', International Journal of Economics \& Business Administration (IJEBA), I(2), pp. 33-48. doi: https://doi.org/10.1089/tmj.2013.0101.

Tekin, G., Yiltay, S. and Ayaz, E. (2016) 'The Effect of Brand Image on Consumer Behaviour: Case Study of Louiss Vuitton-Moet Hennessy', Internatonal Journal of Academic Value Studies, 2(1), pp. 1-24. doi: 10.1109/ISSCC.2007.373461.

Wang, H. et al. (2016) 'Global, regional, and national life expectancy, all-cause mortality, and cause-specific mortality for 249 causes of death, 1980-2015: a systematic analysis for the Global Burden of Disease Study 2015', The Lancet, 388(10053), pp. 1459-1544. doi: 10.1016/S0140-6736(16)31012-1.

Widastra, I. N. (2013) 'Perilaku Masyarakat Dalam Pemanfaatan Pelayanan Kesehatan Gigi Dan Mulut Di Poliklinik Gigi Puskesmas Tabanan I Kabupaten Tabanan', Jurnal Promkes, 1(1), pp. 70-83. Available at: http://210.57.222.46/index.php/JPK/article/vie w/1011. 